\title{
Ensino Religioso e Educação Humanista num Estado leigo
}

\section{Religious Teaching and Humanist Education in a Lay State}

\section{Marcos Sandrini*}

\section{RESUMO}

O presente artigo oferece princípios e definições de conceitos fundamentais para uma adequada compreensão do papel do ensino religioso nas escolas em um estado laico. O método utilizado da correlação de conceitos permitiu clarificar termos utilizados no debate brasileiro sobre este tema, termos tantas vezes usados de maneira parcial ou ambígua. Como consequência, obteve-se uma melhor compreensão do papel do ensino religioso no contexto cultural pluralista brasileiro, bem como detectou-se a necessidade de se propor uma educação humanista. Os princípios de abertura ao transcendente e de hospitalidade são chaves para a compreensão desta educação.

Palavras-chave: Religiosidade. Educação. Humanismo. Estado. Laicidade.

\section{ABSTRACT}

This article offers principles and definitions of fundamental concepts for a proper understanding of the role of religious teaching in schools in a secular state. The method used for the correlation of concepts allowed clarifying terms used in the Brazilian debate on the topic, terms that we often use in a partial or ambiguous way. Therefore, we obtain a better understanding of the role of religious teaching in the Brazilian pluralistic cultural context, as well as the need to propose a humanist education. The principles of openness to the transcendent and hospitality are fundamental to understanding this education.

Keywords: Religiosity. Education. Humanism. State. Secularism.

\footnotetext{
* Faleceu em 23 de outubro de 2018, enquanto esta edição de Teocomunicação estava sendo preparada. Possuía graduação em Letras com especialidade em Francês pela Faculdade Salesiana de Filosofia Ciências e Letras de Lorena, SP (1966), graduação em Filosofia pela Faculdade Salesiana de Filosofia Ciências e Letras de Lorena, SP (1966), graduação em Teologia pela Universidade Pontifícia Salesiana (1972), mestrado em Teologia Pastoral - pela mesma universidade (1977) e doutorado em Educação pela Pontifícia Universidade Católica do Rio Grande do Sul (2007). Ultimamente era Conselheiro Inspetorial da Inspetoria Salesiana São Pio X, presidente da Casa do Pequeno Operário Colégio Dom Bosco de Porto Alegre, Diretor da Faculdade Dom Bosco de Porto Alegre, Coordenador das IUS (Instituições Salesianas de Educação Superior) da América e do Brasil e Coordenador da Pastoral da Educação da CNBB Sul 3. Atuou principalmente nos seguintes temas: pós-modernidade, educação, sistema preventivo, economia solidária e libertação.
} 


\section{INTRODUÇÃO}

Qualquer reflexão sobre ensino religioso deve levar em consideração três realidades. A primeira é que estamos falando de escola. O artigo 210 da Constituição Brasileira diz que:

Serão fixados conteúdos mínimos para o ensino fundamental, de maneira a assegurar formação básica comum e respeito aos valores culturais e artísticos, nacionais e regionais. $\S 1$ o $\mathrm{O}$ ensino religioso, de matrícula facultativa, constituirá disciplina dos horários normais das escolas públicas de ensino fundamental.

Além do mais, estamos falando prioritariamente de escola pública. Toda a realidade da escola impacta sobre a definição da identidade e missão do ensino religioso a ser oferecido no ensino fundamental. É preciso que tenhamos presente que nossa Constituição é bem clara quanto à presença do ensino religioso na escola pública do ensino fundamental. Não é disso que estamos tratando porque já está definido. O que estamos tratando é das decorrências desta definição. Depois, estamos falando de ensino, mais precisamente do processo de ensino/aprendizagem. Tudo o que diz respeito às outras disciplinas também alcança o ensino religioso: objetivos, metodologias, conteúdos, processo de avaliação. Embora seja uma disciplina facultativa para o aluno, não o é para a escola. Neste ponto não são as Igrejas que determinam a identidade do ensino religioso, mas a coordenação pedagógica das escolas e de todo o processo educativo, de acordo com os respectivos sistemas. Não é por nada que a lei de Diretrizes e Bases da Educação Nacional determina (LDBEN) em seu Art. 33, § 1º que

os sistemas de ensino regulamentarão os procedimentos para a definição dos conteúdos do ensino religioso e estabelecerão as normas para a habilitação e admissão dos professores. § $2^{\mathrm{O}}$ Os sistemas de ensino ouvirão entidade civil, constituída pelas diferentes denominações religiosas, para a definição dos conteúdos do ensino religioso.

Finalmente, é preciso uma reflexão aprofundada sobre o significado do termo "religioso" ínsito na caracterização da disciplina. Estes três olhares sobre uma mesma realidade serão levados em consideração nesta minha reflexão. Por isso, trata-se de um desafio complexo.

\section{EXPLICATIO TERMINORUM: DISTINGUIR PARA UNIR}

Nossa primeira abordagem será a definição de alguns termos para entender o Ensino Religioso na Escola Pública brasileira. Explicatio terminorum é uma expressão latina consagrada que significa explicação dos termos, isto é, trata-se de uma dissecação de determinados termos e expressões em seus diversos aspectos. Quando as pessoas utilizam as mesmas palavras, nem sempre estão dizendo a mesma coisa.

\subsection{Religiosidade. Religião. Fé.}

Paul Tillich, teólogo alemão radicado nos EUA por sofrer o exílio imposto pelo nazismo, em sua célebre obra Teologia Sistemática propõe o método da correlação como o mais adequado para o relacionamento entre filosofia e teologia. Para ele o ponto de partida é sempre a situação. 
O polo chamado ‘situação' não pode ser ignorado em teologia sem consequências perigosas. 'Situação', como um polo de todo trabalho teológico, não se refere ao estado psicológico ou sociológico no qual os indivíduos e os grupos vivem. Ela se refere às formas cientificas e artísticas, econômicas, políticas e éticas nas quais eles expressam sua interpretação da existência. A situação que a teologia deve considerar é a interpretação criativa da existência ${ }^{1}$.

Suas obras são um grito por uma religião que não perca sua relevância na vida dos humanos. Seu ponto de partida mais fundamental é a questão da incondicionalidade. Assim ele define a fé como "estar possuído por aquilo que nos toca incondicionalmente"2. O que nos toca incondicionalmente é aquilo que exige "dedicação total". Amar a Deus de todo o coração $(D t 6,5)$ é a preocupação fundamental do Deus da Criação e da Justiça da Bíblia. O Novo Testamento, sobretudo, exige a dedicação total como conseqüência da incondicionalidade. A fé, então, teria a dimensão da centralidade, isto é, envolve a pessoa como um todo. Não só, a fé é um ato de paixão infinita que brota de um ponto de concentração no qual habita a totalidade do ser pessoal. A fé é a orientação da pessoa inteira em direção ao incondicional. $\mathrm{Na}$ verdade, a fé é o poder que cria essa unidade pessoal, isto porque

o incondicional não é um objeto entre outros, e sim a base e origem de todo o ser, e como tal, o centro unificador da vida como pessoa. Estar sem uma preocupação incondicional significa estar sem um centro, pois um ser humano sem centro algum deixaria de ser humano. Por esse motivo não se pode conceber que haja alguém sem uma preocupação incondicional e, portanto, sem fé3.

Tillich afirma que a religiosidade se ocupa das preocupações últimas e a filosofia das preocupações preliminares. Como relacioná-las?

Há três relações possíveis das preocupações preliminares com aquilo que nos preocupa de forma última. A primeira é a indiferença mútua; a segunda é a relação na qual uma preocupação preliminar é elevada à ultimacidade; e a terceira é aquela em que uma preocupação preliminar se torna veículo da preocupação última, sem reivindicar ultimacidade para si mesma ${ }^{4}$.

Para ele, a primeira relação é a que acontece na vida quotidiana quando não há nenhuma correlação entre ambas. A segunda é o que se chama de idolatria. Uma preocupação preliminar se arvora em ultimacidade e, então, há um desequilíbrio e uma desumanização. A terceira, seria a correta e adequada. Qualquer coisa preliminar pode levar à ultimacidade.

Aqui Tillich indica a sua resposta para o dilema entre fé e racionalidade. Qualquer compreensão da fé que implique em contraposição à razão, entendida como fonte de normas e princípios, é desumanizadora e autodestrutiva para a própria fé porque a fé nada mais é que "o ato em que a razão irrompe extaticamente para além de si. Fé como estar possuído em última instância é razão extática"s. A fé, portanto, é um "estado de espírito", por assim dizer; é a integração do espírito na orientação para o incondicionado, no qual "a razão é possuída pelo incondicional", sem que seja quebrada ou destruída.

\footnotetext{
${ }^{1}$ TILLICH, P. Teologia Sistemática, p. 13 e 14

2 TILLICH, P. Teologia Sistemática, p. 5.

${ }^{3}$ TILLICH, P. Teologia Sistemática, p. 69.

${ }^{4}$ TILliCH, P. Teologia Sistemática, p. 25.

5 TILLICH, P. Teologia Sistemática, p.51.
} 
Para ele os conflitos entre fé e razão seriam resultantes da corrupção da fé ou da razão, e a revelação, entendida como evento de manifestação do incondicionado, seria a experiência capaz de restabelecer a relação adequada entre elas.

Para Tillich, "aquilo que toca o homem incondicionalmente precisa ser expresso por meio de símbolos, porque apenas a linguagem simbólica consegue expressar o incondicional" ". No entanto, identificar o incondicionado com os símbolos que o tornam presente é idolatria, pois implica em tratar o condicionado como se fosse incondicionado. "Uma fé que entende seus símbolos literalmente é idolatria" . A verdade religiosa não se encontra, portanto, no sentido literal do símbolo, mas na preocupação expressa através dele. E não pode, em nenhum momento, ser confundida com a verdade científica, histórica ou filosófica. O símbolo de fé é verdadeiro quando, e na proporção em que conjuga a afirmação da presença do incondicional e a negação da própria incondicionalidade.

Ele nos apresenta, então, a possibilidade da existência de diversos tipos de fé. Ele baseia esta possibilidade de diversos tipos de fé na conjugação de dois elementos: a fé ontológica e a fé moral. A fé ontológica seria aquele tipo de fé cuja ênfase está na consciência do fundamento da realidade, na percepção da natureza sacramental da realidade empírica. A fé moral seria a que gravita em torno da exigência moral de Deus, imposta e conferida no dom da lei. Ele continua afirmando que sempre há elementos éticos numa fé sacramental e elementos rituais nas fés morais. Ele chega a afirmar que "a história da fé, que é muito mais ampla do que a história da religião, é uma contínua oscilação de convergência e divergência dos mais diferentes tipos de fé" ". A tensão entre os dois tipos de fé nos ajuda a compreender o problema particular da dúvida. Segundo Tillich, a fé vive "na tensão entre a participação no incondicional e o estar separado dele [...] do elemento de participação advém a certeza da fé; do elemento de separação resulta a dúvida dentro da fé"

Há uma relação e quase uma identificação profunda entre fé e amor. O amor é o impulso para a reunião do separado, a pulsão espiritual que move a pessoa humana na direção do seu fundamento essencial, do qual foi separado na existência. A fé é ser possuído pelo que nos toca incondicionalmente, e o amor é a paixão pelo incondicionado. "A separação entre fé e amor sempre é conseqüência de uma degeneração da religião" Na relação com o incondicionado, a diferença entre fé e amor desaparece.

A filosofia da religião precisa dar conta da experiência religiosa em toda a sua diversidade e riqueza estrutural, e não deveria permitir que a admiração com a unidade e interdependência dos atos e disposições religiosas obscureçam as particularidades e diferenças sutis que encontramos na experiência. A fé é realmente um conceito que abrange uma diversidade coerente de disposições e funções e que, como o amor não pode ser diferenciado de religião, a não ser para fins didáticos.

Hoje a palavra fé causa mais desorientação do que cura. Ela confunde as pessoas, levando a extremos como ceticismo ou fanatismo, resistência pela razão ou sujeição emocional, rejeição de religião genuína ou aceitação acrítica de sucedâneos. Às vezes até surge a tentação de sugerir que se abandone completamente a palavra fé. Mas por mais desejável que seja, isso dificilmente é possível. Uma poderosa tradição está protegendo esta palavra ${ }^{11}$.

${ }^{6}$ TILLICH, P. Teologia Sistemática, p. 30.

7 TILLICH, P. Teologia Sistemática, p. 37.

${ }^{8}$ TILLICH, P. Teologia Sistemática, p. 48.

9 TILLICH, P. Teologia Sistemática, p. 65.

${ }^{10}$ TILLICH, P. Teologia Sistemática, p. 73.

${ }^{11}$ TILLICH, P. Teologia Sistemática, p. 05. 
Uma das formas de atingir o incondicional é através da fé. O místico não está interessado em rejeitar as formas sacramentais concretas da fé, mas em ultrapassá-las. "A experiência mística se encontra ao termo de um longo caminho, que leva das formas mais concretas da fé a um ponto em que todo determinado desaparece no abismo da divindade pura. A mística não é irracional" ${ }^{2}$. O místico encontra-se com o incondicionado através da meditação, contemplação e êxtase. Resumindo, podemos sintetizar o que viemos refletindo e sua relação com o Ensino Religioso.

a) Religiosidade: é a dimensão mais profunda da totalidade da vida humana. É a busca da abertura ao transcendente, àquilo ou Àquele que ultrapassa a superfície da vida, ao sentido radical da existência. Radical nos remete a raiz. É onde nossa vida se enraiza e bebe sua seiva vital. Os maiores inimigos da religiosidade são a alienação e a superficialidade. É por isso que se diz que Deus não se encontra nem antes e nem depois, mas no profundo. .A religiosidade é a face subjetiva, existencial, inerente ao ser humano.

b) Religião: é a vivência comunitária e institucional da religiosidade. A religião é o lado objetivo e social da experiência religiosa. "O ser humano cria ou já encontra diante de si comunidades que vivem uma forma religiosa herdada dos antepassados e estruturada socialmente. É a religião"13. As diversas religiões são maneiras concretas das pessoas viverem a sua religiosidade. Só se pode falar em religião quando a religiosidade é vivida em comunidade.

c) Fé cristã: é uma religião. Se perguntarmos a alguém porque ele é cristão, dirá: “Sou cristão acima de tudo porque através de um conjunto de situações históricas sou e sinto-me chamado por Cristo. E Cristo não só responde satisfatoriamente aos meus questionamentos vitais, como coloca-me diante de perspectivas totalmente novas: mundo novo, homem e mulher novos, nova esperança; sem esquecer também que me propõe questionamentos novos. A minha religiosidade é, pois, enriquecida por Jesus Cristo de maneira tão profunda, única mesmo, que Ele é para mim, o 'lugar' do encontro com Deus. Tudo isto, porém, eu não vivo sozinho: Cristo me chama para uma comunidade de fé, na qual aprendo a me realizar colaborando para a salvação do mundo"14.

O ser humano é um homo religiosus (religiosidade) que vive socialmente essa dimensão (religião) e responde a uma interpelação do Deus revelador (fé) ${ }^{15}$.

Religiosidade, religião e fé ora se distanciam ora se entrelaçam. Assim, a religião responde e não responde à religiosidade. A religião vive e não vive da fé. A experiência religiosa pode ser de Deus e pode não ser de Deus. A experiência de Deus pode ser religiosa e pode não ser religiosa.

Dois extremos espreitam as religiões: a intolerância, o fanatismo, a intransigência, de um lado, e o indiferentismo, o relativismo, o sincretismo de outro. Não ao indiferentismo diante de tudo e sim à rejeição a qualquer pretensa ortodoxia absolutista. Não ao relativismo de todo absoluto e sim à maior sensibilidade para a relatividade de todos os absolutismos humanos que bloqueiam uma coexistência criativa entre as diferentes religiões. As religiões são tessitura de relações. Não sincretismo no qual tudo, o possível e o impossível, é misturado,

${ }^{12}$ TILLICH, P. Teologia Sistemática, p. 42.

${ }^{13}$ LIBÂNIO, J. B. A religião no início do milênio, p. 99.

${ }^{14}$ GRUEN, W. O Ensino Religioso na escola oficial, p. 29.

${ }^{15}$ LIBÂNIO, J. B. A religião no início do milênio, p. 99. 
fundido e sim à síntese que supera contradições e antagonismos dolorosos. Não a uma atitude de pura negação do outro e sim à aceitação deliberada do contexto plural como valor. Numa palavra, saber compor: abertura e verdade, pluralidade e identidade, disposição ao diálogo e firmeza de posição ${ }^{16}$.

Há sempre uns cantos de sereia rondando as religiões aos quais é preciso se fechar. Voltar aos tempos pré-modernos pode significar certo reflorescimento das religiões, mas não será profecia nem para o presente e nem para o futuro. Ensopar-se com a modernidade pode significar encanto com a razão, a ciência e a técnica, mas também não significa profecia para as grandes exclusões que causam sofrimento e dor num mundo que aprendeu a concentrar para além do imaginável. A modernidade criou grandes mitos, quais sejam, o desenvolvimento ilimitado, o progresso tecnológico assombroso, a democraia e liberdade, a melhoria das condições sociais da humanidade. Acolher os ideais dos novos paradigmas que escondem uma religião que se transforma em objeto de consumo na vitrine multicolorida do mercado significa um sem-sentido sem ética e sem religião. Há religiões e igrejas que anestesiam qualquer crítica social e abre enorme espaço comercial, fazendo circular milhões de dólares. Resumindo o que viemos apresentando ainda é Libânio quem dá um resumo magistral

\begin{abstract}
A religião enquanto instituição caracteriza-se pela sua visibilidade de ritos, símbolos, templos, ministros, doutrinas. Tem como dimensões básicas, a tradição e a comunidade. A religiosidade aponta para o traço pessoal, para as experiências subjetivas, para as expressões livres e espontâneas, não necessariamente regidas pelos cânones da instituição. A fé, por sua vez, relaciona-se principalmente com uma revelação, com uma Palavra transcendente que se acolhe com todas as suas exigências. Embora distintos, os campos entremesclam-se. A religião tende a responder os reclamos da religiosidade. A fé institucionaliza-se em religião e vincula-se também com a dimensão de religiosidade das pessoas. No entanto, a distinção permite entender melhor o atual fenômeno ${ }^{17}$.
\end{abstract}

\title{
1.2 Confessionalidade
}

Causou certa perplexidade e novidade no ordenamento jurídico brasileiro o artigo 11 do Acordo Brasil-Santa Sé que diz:

O ensino religioso católico e de outras confissões religiosas, de matrícula facultativa, constitui disciplina dos horários normais das escolas públicas de ensino fundamental, assegurado o respeito à diversidade cultural religiosa do Brasil, em conformidade com a Constituição e as outras leis vigentes, sem qualquer forma de discriminação ${ }^{18}$.

A perplexidade aconteceu e acontece porque há alguns elementos que nunca apareceram no ordenamento jurídico brasileiro, nem nas diversas Constituições Brasileiras e nem nas sucessivas Leis de Diretrizes e Bases da Educação Nacional (LDBEN). A principal delas é o termo "ensino religioso católico e de outras confissões religiosas". Lendo com atenção este artigo pode-se ver que esta expressão deve ser conjugada com os termos "diversidade cultural religiosa" e "discriminação". Em nenhum momento se fala em ensino religioso "confessional" católico. Parece-nos que isto não

\footnotetext{
${ }^{16}$ LIBÂNIO, J. B. A religião no início do milênio, p. 195.

${ }^{17}$ LIBÂNIO, J. B. A religião no início do milênio, p. 268.

${ }^{18}$ Apud ALBERTON, G. da S. Laicidade na Relação Igreja-Estado e o Acordo Brasil-Santa Sé, p. 170.
} 
coloca uma pá de cal nas iniciativas de interconfessionalidade e interreligiosidade que acontecem em termos de Ensino Religioso com o aval dos sistemas de ensino.

A própria etimologia da palavra católico é muito significativa. Ela vem do termo grego "katholikós", que é a combinação de duas palavras: "kata" - concernente e "holos" - totalidade; por consequência, "concernente à totalidade", "relativo à totalidade" ou "integral, abrangente". Papa Francisco diz que a igreja é católica em três sentidos ${ }^{19}$. Primeiro, porque é o espaço, a casa na qual vem anunciada toda a fé, por inteiro, na qual a salvação que nos trouxe Jesus é oferecida a todos. Segundo, a Igreja é católica porque é universal, está espalhada em toda parte do mundo e anuncia o Evangelho a todo homem e a toda mulher. A Igreja não é um grupo de elite, não diz respeito somente a alguns. A Igreja não tem trancas, é enviada à totalidade das pessoas, à totalidade do gênero humano. Terceiro, a Igreja é católica porque é a "Casa da harmonia" onde unidade e diversidade combinam-se para ser uma riqueza. Pensemos na imagem da sinfonia, que quer dizer acordo, harmonia, diversos instrumentos tocando juntos; cada um mantém o seu timbre inconfundível e as suas características de som têm algo em comum. A catolicidade respeita a diversidade cultural religiosa contra qualquer discriminação.

Queremos nos ater a este terceiro sentido. A igreja é católica porque é a casa da hospitalidade. Nós não somos católicos, nós nos vamos tornando católicos. Para $\operatorname{Boff}^{20} \mathrm{a}$ hospitalidade é utopia e prática, integra o sonho e a realidade em suas margens. Ou, como ele mesmo diz, a hospitalidade é antes de mais nada uma disposição da alma, aberta e irrestrita. Ela, como o amor incondicional, em princípio, não rejeita nem discrimina a ninguém. É simultaneamente uma utopia e uma prática. Como utopia representa um dos anseios mais caros da história humana: de ser sempre acolhido independente da condição social e moral e de ser tratado humanamente. Como prática cria as políticas que viabilizam e ordenam a acolhida. Mas por ser concreta sofre os constrangimentos e as limitações das situações dadas. Nestes tempos complexos e frágeis em que vivemos, a hospitalidade aponta para um modelo de relação a ser resgatado, no qual se compartilha cuidados e conhecimentos, no qual se aguarda e atenta para o outro.

Há um importante estudo de Wolfgang Gruen ${ }^{21}$ sobre questões que envolvem a confessionalidade do Ensino Religioso. Mesmo que o acordo Brasil/Santa Sé tenha definido que o Ensino Religioso na escola pública será “católico ou de outras religiões", ele não se pode transformar em catequese pura e simplesmente porque seria uma capitulação não do Ensino Religioso, mas da catequese uma vez que a escola não é lugar propício e adequado para a catequese, pois lhe falta a dimensão da comunidade. Isto reforça o dualismo fé/vida. Neste sentido é que se pode e (talvez) se deva reforçar o ensino religioso na linha da religiosidade.

Os Atos dos Apóstolos 2,42 indicam para qualquer atividade eclesial, no caso a catequese, quatro dimensões: "Perseveravam na doutrina dos apóstolos (querigma), na comunhão fraterna (koinonia), na fração do pão (diakonia) e nas orações (liturgia)". Não é possível realizá-las todas e de forma integral na escola e numa disciplina específica.

Ao afirmar o ensino religioso católico a Igreja Católica se preocupará com sua efetivação, uma vez que o Acordo Brasil-Santa Sé é bilateral. A Lei de Diretrizes e Bases da Educação Nacional (LDBEN) determina em seu Art. 33, §1 que "os sistemas de ensino regulamentarão os procedimentos para a definição dos conteúdos do ensino religioso". Os sistemas de ensino federal, estadual e municipal têm seus conselhos para

${ }^{21} \mathrm{Cf}$. W. GRUEN. O Ensino Religioso em movimento. 
esta definição. A presença da Igreja Católica nestes espaços é fundamental, sobretudo através dos cristãos católicos que deles participam. A Igreja Católica manifestará seu apoio e oferecerá subsídios a eles, dentro dos marcos da legislação vigente e no respeito a todos, sobretudo das minorias. Isto não significa que o ensino religioso seja transformado em catequese ou numa salada mista tão grande que as novas gerações não encontrarão espaço para expor suas ideias e criar convicções que desemboquem em projeto de vida. Defendendo o ensino religioso como educação da religiosidade, segundo falamos na seção anterior, não cairemos no perigo apresentado pelo Ministro Celso de Mello em seu voto na ADI 4.451:

Disso tudo resulta, segundo penso, que, em matéria confessional, o princípio da laicidade do Estado-matriz de que emana, entre outras prerrogativas essenciais, a liberdade religiosa - será efetivamente respeitado se, tratando-se de ensino religioso, este não tiver conteúdo confessional, interconfessional ou ecumênico, pois, nesse específico domínio, o aparelho estatal, para manter posição de estrita neutralidade axiológica, não poderá viabilizar, na escola pública, a ministração de aulas que se refiram a uma $o u$ a algumas denominações religiosas ${ }^{22}$.

A atual LDBEN no mesmo artigo acima citado afirma que os sistemas de ensino "estabelecerão as normas para a habilitação e admissão dos professores". A habilitação e a admissão competem aos sistemas de ensino e não às denominações religiosas ou ao ateísmo, ainda mais que o ônus com o ensino religioso é de competência dos respectivos sistemas de ensino. No ensino religioso é preciso afirmar consensos. Consenso, no entanto, não é concessão. Para dialogar é preciso que cada pessoa se apresente com sua identidade e seu fundamento. Quem não sabe o que é e o que defende não vai a lugar nenhum. Já dizia Aristóteles que para quem não sabe para onde vai todo vento é favorável. A formação dos professores é tarefa dos sistemas de ensino, mas a Igreja Católica não se pode omitir e pode e deve organizar espaços de formação nas dioceses que são as Igrejas locais, a partir do princípio da subsidiariedade. Trabalhar a identidade do professor de ensino religioso que professa a fé católica é fundamental. Isto não significa quebrar a laicidade do estado uma vez que a lei 9.475 , artigo 33, de julho de 1997 (LDBEN) afirma que "o ensino religioso, de matrícula facultativa, é parte integrante da formação básica do cidadão". É importante assinalar que a lei afirma que o ensino religioso é parte integrante da formação básica do cidadão. Sendo assim, não há intromissão indevida na legislação e na prática da educação brasileira, uma vez que sendo básica, se faltar, a base da formação do cidadão não estará completa.

A pessoa de Jesus Cristo é paradigmática nesta formação do professor de ensino religioso.

O que mais caracteriza o Deus de Jesus é sua humanidade. Com isso quero dizer que o Deus que se revelou a nós em Jesus pode ser encontrado antes de tudo no humano, mais que no sagrado, no religioso e no espiritual, como algo contraposto ao que é pura e simplesmente humano. Consequentemente, o Deus de Jesus se encontra, antes de tudo, no laical, não no sagrado, no religioso e no espiritual. Portanto, o sagrado, o religioso e o espiritual são autênticos, aceitáveis e instrumentos para encontrar a Deus na medida, e apenas na medida, em que nos humanizam, nos tornam mais basicamente humanos, ou seja, nos fazem coincidir com aquilo em que todos os seres humanos somos iguais e, portanto, nos levam a identificarmo-nos com aquilo em que todos coincidimos ${ }^{23}$.

\footnotetext{
${ }^{22}$ MELLO, C de. Voto. Ação Direta de inconstitucionalidade, n. 4.451 (21.06.2018).
}

${ }^{23}$ CASTILLO, J. M. Jesus: a humanização de Deus, p. 300. 


\subsection{Educação à fé. Educação da Fé. Educação na Fé.}

A partir do que estamos expondo podemos fazer ainda uma tríplice distinção: educação à fé, educação na fé, educação da fé.

A educação à fé seria a preparação da pessoa para receber o dom da fé. Esta seria a educação das perguntas existenciais, é a abertura à radicalidade. Há um provérbio chinês que diz que "enquanto o tolo olha o dedo, o sábio olha a lua". O importante não é o dedo, mas a lua. O dedo apenas aponta, ele é sinal, ele não é a lua, que é a verdadeira realidade. Há muitos dedos apontando para o transcendente e a transcendência.

A educação na fé significa que uma pessoa já fez sua pergunta existencial e já acolheu o dom da fé, então precisa continuar se educando para que a fé possa continuar agindo nela.

A educação da fé é impossível. Como vamos educar a fé se ela é um dom e não depende de nós, em primeiro lugar, mas do próprio Deus?

Vamos dar um exemplo de relação entre educação à fé e educação na fé. Puebla fala de injustiça institucionalizada e de pecado social.

Vemos, à luz da fé, como um escândalo e uma contradição com o ser cristão, a brecha crescente entre ricos e pobres. O luxo de alguns poucos se converte em insulto contra a miséria das grandes massas. Isto é contrário ao plano do Criador e à honra que lhe é devida. Nesta angústia e dor, a Igreja discerne uma situação de pecado social ${ }^{24}$.

Para que um cristão possa entender que o pecado é social e estrutural é preciso que ele entenda outras dimensões da pobreza que o documento afirma em várias de suas partes. Assim, do ponto de vista econômico a pobreza é uma exploração. Do ponto de vista político é uma opressão. Do ponto de vista ético é uma injustiça. Se a pessoa entender isso, lhe será muito mais fácil entender que a pobreza é um pecado social.

Educar na fé pressupõe a educação à fé. Estas duas realidades podem e devem ser feitas concomitantemente, isto é, ao mesmo tempo. É interessante que a parábola do semeador (Mt 13, 1-23) não questiona nem a semente e nem quem semeia. Questiona apenas e tão somente o terreno onde a semente é jogada. Preparar o terreno é a grande jogada. De certa maneira é o que faz Sócrates quando diz que não ensina nada a ninguém. É o que faz Paulo Freire quando diz que ninguém educa ninguém e ninguém se educa sozinho, mas todos nos educamos mediados pela práxis. É o que diz Paul Tillich quando diz que mais que respostas, a educação deve abrir as pessoas para se perguntar. Sem isto não há convencimento, não há empolgação e nem sedução.

\subsection{Espiritualidade e Espiritualidades}

A vida não se pode reduzir ao econômico, ao financeiro, ao tecnológico. Há outros olhares que precisam ser levados em consideração. Toda unidimensionalidade é portadora de morte. Apostar no futuro de uma criança não pode significar apenas olhar para sua competência profissional para ganhar riquezas, desfrutar de uma posição social e sair-se bem na vida. Uma criança aspira a muito mais que isto.

Até no processo de aprendizagem a racionalidade é uma das possíveis visões da pessoa. As inteligências múltiplas o provam sobejamente. Howard Gardner foi quem mais aprofundou a dimensão das inteligências múltiplas. A pluralidade de visões de

${ }^{24}$ III CONFERENCIA GENERAL DEL EPISCOPADO LATINO-AMERICANO, Puebla. Conclusões, n. 28. 
mundo, a globalização e 'planetarização' do mundo possibilitaram a emergência e a convivência com diferentes visões de vida. Um simples olhar para as concepções religiosas do ocidente e do oriente verá que ambas são unidimensionais e, colocadas em confronto, uma pode e deve aprender com a outra.

É muito comum encontrarmos pessoas que dizem ter ou não ter espiritualidade. Normalmente quando se fala em espiritualidade se opõe à materialidade. Isto é fruto de uma visão grega da vida. Como os gregos tinham uma aversão à matéria, sobretudo por motivos econômicos uma vez que precisavam de escravos para trabalhar com a matéria, tudo o que se fazia que envolvesse o corpo significava inferioridade e perigo para a alma, para o espírito. Até hoje continuamos com esta visão. O espírito se sobrepõe à matéria. No entanto, espírito significa vida, animação. O que se sobrepõe ao espírito, à vida não é a matéria, mas a morte. Há situações de vida e situações de morte. Há pessoas com grande sensibilidade para defender e promover a vida e pessoas com maquinações para promover a morte, a violência.

Uma boa espiritualidade é aquela que consegue incluir em si também a matéria, o corpo, o econômico. É por isso que há pessoas que se dizem muito espiritualizadas que pouco ou nada fazem para promover a vida. Faz parte da autêntica espiritualidade saber conviver pacificamente com a própria corporeidade, com os bens, com o dinheiro. Faz parte da espiritualidade a luta pela defesa da dignidade da pessoa humana, de todas as pessoas, não apenas de algumas. Faz parte da espiritualidade a oração, mas também a caridade, a solidariedade, a participação política, a dignificação das profissões, a luta pela implantação da justiça social.

Rafael Yus ${ }^{25}$ apresenta oito perspectivas como se entende e se pratica a espiritualidade hoje em relação à educação. Espiritualidade como religião; espiritualidade como sentido da vida; espiritualidade como autorreflexão; espiritualidade como conhecimento místico; espiritualidade como emoção; espiritualidade como moralidade; espiritualidade como ecologia; espiritualidade como criatividade.

\subsection{Pastoral da Educação e Pastoral Escolar}

Dada a complexidade da educação e da sua importância fundamental para a formação da pessoa e da sociedade, deve haver na organização pastoral da Igreja (paróquias, dioceses, regionais) um setor que cuide, de maneira articulada e organizada da pastoral da educação. É urgente que esse setor seja apoiado e dinamizado e, quando não existe, seja organizado ${ }^{26}$.

A pastoral da educação abrange a todos os cristãos em sua atuação no mundo da escola e a todos os processos educativos. Toda pastoral é orgânica. Ela não trata do agir individual e pessoal de cada cristão, mas de cristãos que querem viver sua fé na Igreja e atuar na sociedade, no caso no mundo da escola, de forma orgânica, metódica e sistemática.

A pastoral da educação é a ação da Igreja para continuar a presença e a atuação do Senhor Jesus, no mundo da educação. É o esforço sistemático (não ocasional, mas metódico), orgânico (não isolado, mas inserido na pastoral de Conjunto) que o Povo de Deus faz para refletir e pôr em prática a mensagem evangélica na educação. É a evangelização do educativo. O centro de toda a mensagem de Jesus é o Reino. A pastoral da educação visa proclamar e construir o Reino de Deus no mundo da educação ${ }^{27}$.

${ }^{27} \mathrm{CNBB}$, Educação, Igreja e Sociedade, p. 57. 
Faz parte da pastoral da educação todo o esforço para evangelizar a escola. É pastoral da educação o engajamento dos cristãos na luta pela democratização da escola em seus três sentidos complementares. O primeiro deles é o acesso de todos à escola. O segundo é a democratização interna tocando as questões das relações internas, do poder dentro da instituição e do conteúdo transmitido. Por último, a democratização social como inserção da escola no seu entorno e na realidade social. Neste sentido a Pastoral da Educação preocupa-se em evangelizar a própria escola. Nossas escolas, suas próprias estruturas têm muito de exclusão, omissão e alienação.

Já a Pastoral Escolar é o conjunto das ações feitas na escola sempre na linha da opção. São ações planejadas para trabalhar a dimensão especificamente religiosa na comunidade escolar. Isto é muito difícil na escola estatal, mas não impossível. Nas escolas confessionais é prioritária a existência de um setor para trabalhar com pastoral escolar. Assim como há um setor de orientação pedagógica, de orientação educacional, há também um setor de orientação religiosa ou de animação pastoral. Sua tarefa é responsabilizar-se pela constituição de grupos de reflexão e de oração, por celebrações, eventualmente pela catequese na comunidade escolar, pela organização do ERE em conjunto com a Coordenação pedagógica, por dias de formação e retiros, pelo conhecimento bíblico, pelo cultivo vocacional na linha do "bom cristão e honesto cidadão", pelo voluntariado, pelo cultivo da dimensão da missionariedade. Isto nos parece irrenunciável por parte das Escolas Católicas.

\subsection{Educar evangelizando e evangelizar educando}

Para o educador cristão, a ação evangelizadora pastoral tem uma dimensão educativa e a educação tem uma dimensão evangelizadora pastoral. Toda pastoral tem que ter a dimensão educativa bem pensada sob pena de perder sua eficiência e eficácia. Um sermão, um encontro catequético, uma reunião de grupo de jovens tem que preocupar-se com sua dimensão educativa. Se não for educativa também não será pastoral.

O educativo passa pela reflexão dos itinerários, das metodologias, dos objetivos, da avaliação. A prática pastoral será libertadora se for baseada numa pedagogia libertadora. Pode haver uma ação pastoral manipuladora, de pura domesticação e socialização religiosa. Toda pastoral precisa de uma metodologia adequada. Palavras libertadoras carregadas por mãos domesticadoras é um contra-senso. Todo pastor enquanto evangeliza (des-)educa.

Há pessoas, grupos e instituições que, por vocação e opção, evangelizam educando. Um professor cristão evangeliza educando. Uma instituição educacional católica evangeliza educando. Um grupo de teatro, de educação de jovens e adultos (EJA) evangeliza educando. Por isso é que dizemos que a pastoral da educação é a presença e a ação da Igreja, proclamando e construindo o Reino de Deus no e através do mundo da educação.

\subsection{Laicidade}

Cada vez mais cresce entre os humanos a consciência de que a solução bélica dos conflitos está-se tornando insuportável. Após duas grandes guerras mundiais, 1914 e 1939, tomaram-se duas grandes resoluções. A primeira foi a constituição da Organização das Nações Unidas (ONU) com seus altos e baixos, suas alegrias e suas decepções. Não resta dúvida, no entanto, que a ONU representa efetivamente o grande desejo de frear o espírito belicoso entre as nações, sobretudo a partir das nações centrais hegemônicas 
de onde partem as declarações de guerra mais abrangentes e mais cruéis. A segunda, foi a Declaração Universal dos Direitos Humanos que aconteceu em 1948, portanto, há setenta anos. Esta declaração veio afirmar que os conflitos não se resolvem com a eliminação de uma das partes nas com a criação de consensos cada vez mais abrangentes entre as partes. A linguagem do consenso é uma conquista da humanidade, inclusive das religiões. Do ponto de vista religioso muito contribuiu para isto a convicção de que não haverá paz no mundo se não houver paz entre as religiões e o avanço do conceito de estado laico. O estado precisa ser laico e necessita da ajuda de sabedoria inclusive religiosa para governar bem esta pluralidade.

A melhor maneira que as sociedades modernas inventaram para administrar este pluralismo foi o "estado laico". Justamente após o período de confrontações internas ao cristianismo europeu, as chamadas guerras de religião, o Estado laico, fortalecido por uma filosofia política fundada no consenso e no contrato constitucional, começou a surgir como solução de conflitos ${ }^{28}$.

A Constituição Brasileira de 1824 em seu artigo quinto dizia que "a Religião Catholica Apostolica Romana continuará a ser a Religião do Imperio. Todas as outras Religiões serão permitidas com seu culto doméstico, ou particular em casas para isso destinadas, sem forma alguma exterior do Templo". A proclamação da República marcou um corte nesta visão e nesta legislação. O Decreto no 119-A de 07 de janeiro de 1890 redigido por Rui Barbosa tratou de transformar o sistema de relação entre Religião e Estado. Deixamos de ser um Estado confessional para ser um Estado laico antes mesmo da primeira Constituição Republicana. A Constituição de 1891 foi um marco legal importante na separação entre Igreja e Estado com a proclamação expressa do estado laico. O art. 72, §6 diz que "será leigo o ensino ministrado nos estabelecimentos públicos".

Isto significa três coisas. Primeiro, que há uma nítida divisão entre o poder secular ou temporal e o poder espiritual. Segundo, a neutralidade do estado em relação à religião não tendo preferência e nem aversão por nenhuma delas. Finalmente, o respeito incondicional à liberdade religiosa, respeitando todas as opções religiosas bem como a não opção religiosa por parte de qualquer cidadão. Com isto se diz que o estado brasileiro é laico, mas não é ateu e nem anticlerical. "A constituição de 1891 escapou de ser nitidamente anticlerical, para ser, apenas, laica. Tolerava-se, mas não se combatia frontalmente a religião"29. Muitos viram nisso um grande benefício para a religião e, no caso, para a Igreja Católica. Despojada de poder, mas livre.

A Constituição de 1934 em seu artigo 153 diz que "o ensino religioso será de frequência facultativa e ministrado de acordo com os princípios da confissão religiosa do aluno manifestada pelos pais ou responsáveis e constituirá matéria dos horários nas escolas públicas primárias, secundárias, profissionais e normais". Isto é uma quebra da afirmação do ensino laico da Constituição de 1891. Daí para frente todas as Constituições brasileiras reafirmaram este princípio com alterações pontuais. Assim, nas Constituições de 1937, na de 1946, na de 1967, na de 1969. A Constituição de 1988 segue a mesma linha com esta redação em seu artigo 210, parágrafo primeiro: “O ensino religioso, de matrícula facultativa, constituirá disciplina dos horários normais das escolas públicas de ensino fundamental". Resumindo o que viemos dizendo até aqui sobre laicidade reportamos trecho de voto do Ministro Celso de Mello na ADPF 54:

${ }^{28}$ SUSIN, L. C. O ato de religião como virtude e seus vícios. Sobre fundamentalismo, fanatismo, esquizocrentes: patologias e remédios, p. 214.

${ }^{29}$ TÔRRES, J. C. de O. A Democracia Coroada, p. 405. 
A laicidade do Estado, enquanto princípio fundamental da ordem constitucional brasileira, que impõe a separação entre Igreja e Estado, não só reconhece, a todos, a liberdade de religião (consistente no direito de professar ou de não professar qualquer confissão religiosa), como assegura absoluta igualdade dos cidadãos em matéria de crença, garantindo, ainda, às pessoas, plena liberdade de consciência e de culto. O conteúdo material da liberdade religiosa compreende, na abrangência de seu significado, a liberdade de crença (que traduz uma das projeções da liberdade de consciência), a liberdade de culto e a liberdade de organização religiosa, que representam valores intrinsecamente vinculados e necessários à própria configuração da ideia de democracia, cuja noção se alimenta, continuamente, dentre outros fatores relevantes, do respeito ao pluralismo" ${ }^{\prime 30}$.

\section{EDUCAÇÃO HUMANISTA}

A recente Constituição Apostólica Veritatis Gaudium do Papa Francisco sobre as universidades e as faculdades eclesiásticas apresenta quatro critérios para renovação e relançamento da contribuição dos estudos eclesiásticos para a missão da Igreja em saída.

O primeiro critério é "a contemplação e a introdução espiritual, intelectual e existencial no coração do querigma, ou seja, da feliz notícia, sempre nova e fascinante, e o Evangelho de Jesus" ${ }^{31}$. É a capacidade de ver no outro o rosto de Deus revelado por Jesus fazendo a opção pelos últimos, pelos excluídos e descartados.

O segundo critério é o diálogo sem reservas, a cultura do encontro, o diá-logo com os aderentes a outras convicções religiosas ou humanistas. O apelo do Papa é candente. "É importante chegar aonde são concebidas as novas histórias e paradigmas" 32 . Se dizemos que estamos numa mudança de época, numa mudança de paradigma, onde estes paradigmas estão sendo gestados e por quem?

O terceiro critério é "a interdisciplinaridade e a transdisciplinaridade exercidas com sabedoria e criatividade á luz da Revelação" 33 . É a capacidade de saber unir os contrários na graça da unidade. Assim, coesão com flexibilidade; organicidade com dinamicidade. É preciso passar da interdisciplinaridade e da multidisciplinaridade para a transdisciplinaridade. Não basta colocar as disciplinas e a visões de mundo juntas se não houver capacidade de diálogo e mútua colaboração.

O quarto critério invoca "a necessidade urgente de 'criar rede' entre as várias instituições que, em todas as partes do mundo, cultivam e promovem os estudos eclesiásticos, ativando decididamente as oportunas sinergias também com as instituições acadêmicas dos diferentes países e com as que se inspiram nas várias tradições culturais e religiosas, dando vida simultaneamente a centros especializados de investigação com a finalidade de estudar os problemas de grandeza epocal que hoje investem a humanidade, chegando a propor pistas oportunas e realistas de resolução"34.

Estes quatro critérios servem muito bem para uma reflexão sobre a educação humanista que é o grande objetivo do Ensino Religioso. Desta educação humanista queremos ressaltar apenas alguns poucos elementos.

\footnotetext{
${ }^{30}$ MELLO, C. de. Voto. Arguição de Descumprimento de Preceito Fundamental 54 (12.4.2012).

${ }^{31}$ FRANCISCO. Constituição Apostólica Veritatis Gaudium sobre as Universidades e as Faculdades Eclesiásticas, p. 16.

${ }^{32}$ FRANCISCO. Veritatis Gaudium, p. 20.

${ }^{33}$ FRANCISCO. Veritatis Gaudium, p. 20.

${ }^{34}$ FRANCISCO. Veritatis Gaudium, p. 23.
} 


\subsection{Educação atenta aos novos paradigmas}

Muitos documentos da Igreja Católica falam de mudança de época como mudança de paradigma. Um paradigma é uma maneira de conceber o mundo, uma visão de mundo. Não são todos os autores que aceitam que estejamos numa mudança de época. Habermas, por exemplo, diz que estamos vivendo uma hipermodernidade. A mudança de época pode ser lida sob duas óticas: a diacrônica e a sincrônica. Diacronicamente pode-se dizer que as idades (cronos) se sucedem através dos (diá) tempos. Assim, por exemplo, da pré-modernidade se passaria para a modernidade e desembocaria na pós-modernidade. Do ponto de vista sin-crônico podemos dizer que todas estas idades são vividas ao mesmo ( $\sin )$ tempo (cronos). Assim, em 2018 todos estaríamos no mesmo tempo cronológico, mas não estaríamos no mesmo tempo histórico. Esta é a perspectiva mais adequada para a leitura da assim chamada mudança de época. Hoje teríamos sinais de uma nova época, de um novo paradigma. Por isso existem visões diferentes sobre a mesma realidade podendo levar a situações fortes de conflitividade. Um novo horizonte está surgindo.

Estamos mudando de paradigma civilizacional. Com isso queremos dizer (e com isso já estamos explicando o que seja paradigma) que está nascendo um outro tipo de percepção da realidade, com novos valores, novos sonhos, nova forma de organizar arquitetonicamente os conhecimentos, novo tipo de relação social, nova forma de dialogar com a natureza, novo modo de experimentar a última Realidade e nova maneira de entendermo-nos a nós mesmos e de definir nosso lugar no conjunto dos seres. O novo paradigma nascente se opera em progressivas travessias: passamos da parte para o todo, do simples para o complexo, do local para o global, do nacional para o planetário, do planetário para o cósmico e do cósmico para o mistério e do mistério para Deus ${ }^{35}$.

Apresento, agora, seis grandes passagens que são sinais do advento deste novo paradigma.

O primeiro é a passagem do paradigma da ciência técnica moderna e seus postulados ao novo paradigma da ciência complexa. A ciência pré-moderna se baseava no argumento da autoridade magister dixit, isto é, o professor falou está certo porque ele é o professor. Esta visão foi abalada de forma profunda e irreversível pela Renascença e, mais tarde, pelo movimento cultural-filosófico do Iluminismo. Nascia, então, uma nova idade denominada Revolução Científica, que desvinculou o profano do sagrado, destacando a razão como valor fundamental juntamente com a liberdade de pensamento, e erigindo como meta a bandeira do progresso. O mundo nada mais é que uma sequencia de causas e efeitos que, uma vez descobertas, o coloca nas mãos da pessoa humana.

Por um lado isto é fantástico porque possibilitou um progresso científico extraordinário. As revoluções industriais só se tornaram possíveis com o desenvolvimento científico que possibilitou estupendas descobertas técnicas e tecnológicas. Os cientistas, igualmente, procuraram aplicar estas leis da natureza às relações sociais. Então, temos os grandes sistemas, as grandes ideologias. Durkheim dizia que era preciso reduzir os fatos sociais às suas dimensões externas, observáveis e mensuráveis. Por outro lado, esta visão científica da realidade tem como consequência o desencantamento do mundo e a crise ecológica.

${ }^{35} \mathrm{BOFF}, \mathrm{L}$. Virtudes para um outro mundo possível, p. 27 e 28. 
Contra esta visão científica surge o paradigma complexo. O mundo não apenas precisa ser explicado e dominado, mas interpretado e transformado. $\mathrm{O}$ mundo não é simples, ele é complexo (cum-plexus). Uma visão científica linear não consegue captá-lo por inteiro. A complexidade nunca pode ser simplificada, já que o complexo, por sê-lo, não pode ser simplificado. O complexo não é complicado; ele é a antítese do simples. Esta teoria da complexidade recupera dimensões esquecidas ou mesmo nunca achadas. A racionalidade não explica por inteiro a realidade. A intuição, as imagens, as sensações, a poesia, o pensamento mágico, também ajudam, em grande grau, a completar o conhecimento harmônico e ordenado da realidade. A nova realidade da ciência exige uma nova narração. Costuma-se dizer que as mesmas causas produzem os mesmos efeitos, mas também os efeitos modificam as causas porque tudo age em rede. "Abordar o conhecimento social, e também o educativo, significa, hoje em dia, dar conta da inovação, do movimento e da complexidade" "36. O paradima moderno não tem condições de trabalhar com a complexidade e com a rede que vige na sociedade da globalização, da mundialização e das novas tecnologias.

O segundo é a passagem do pensamento forte ao pensamento fraco e complexo. Esta visão científica também está ancorada numa visão filosófica. Se é possível descobrir as leis que regem o mundo, também é possivel definir o ser de todas as coisas. Assim, a filosofia, sobretudo a ontologia, nada mais é que a construção do estatuto do ser e de sua estrutura estável. A filosofia é um conhecimento absoluto, porque conhecimento dos verdadeiros princípios de todo o saber. Kant o chama de conhecimento transcendental porque seu objetivo é chegar aos fundamentos últimos e seguros, àquela base eterna e imutável que constitui a própria racionalidade humana enquanto tal.

Hoje há uma forte crítica a esta visão. Hannah Arendt e Zigmunt Bauman dizem que esta visão filosófica deu sustentação ao genocídio judeu e aos horrores da segunda guerra mundial. Isto porque se há apenas um pensamento forte, o pensamento do outro ou o outro pensamento não tem valor. Então ele precisa ser eliminado ou absorvido. Também aqui se aplica o princípio da complexidade. Não é possível este pensamento forte porque incapaz de captar a inteireza do ser. Nunca há uma adequação do pensamento com a coisa como o quer a modernidade. O ser é uma coisa e, o pensamento sobre o ser é outra. Propugna-se, então, pela existência do pensamento fraco que possibilita o pluralismo de pensamento. Quem não pensa como eu também pensa.

Neste contexto, à racionalidade está reservada outra função que não a de encontrar o pensamento forte, luminoso, estável, único, forte, cartesiano, mas também o caminhar na penumbra. Dentro do paradigma da complexidade está embutida a impossibilidade de um olhar absoluto sobre o mundo e a história. A nova época não propugna mudança de fundamento, mas afirma que há fundamento, mas fraco. Mais radicalmente ela afirma que não há uma mudança de fundamento, mas a abolição de qualquer fundamento dando suporte ao relativismo.

O terceiro é a passagem da história como civilização e progresso linear à experiência do fim da história. A modernidade vê a história como uma caminhada progressiva rumo a uma civilização. Não há pluralidade de histórias, mas uma única e mesma história. Há povos mais adiantados e povos mais atrasados. A humanidade caminha irreversivelmente rumo à emancipação, à maioridade, ao progresso civilizatório. Uma das consequências desta visão é o colonialismo e as guerras de conquista. $\mathrm{O}$ grande problema é quem determina o nível de civilização. Na modernidade ocidental foi o masculino, o branco, o europeu (ocidental), o adulto e o cristão. O outro é o não-branco,

${ }^{36}$ COLOM, A. J. A (Des)Construção do Conhecimento Pedagógico, p. 81. 
o não-masculino, o não-cristão, o não-europeu, o não-adulto. Esta visão foi responsável pela conquista da América e o consequente genocídio de seu povo.

Interpretar a história como progresso é uma falácia comum. Vemos os desenvolvimentismos recentes como melhorias quase inevitábeis em relação ao passado. Mas o presente não está fatalmente ligado ao passado, nem sempre representa um progresso em relação a este ${ }^{37}$.

O novo paradigma afirma que chegamos ao fim da história. É o reconhecimento do pluralismo sem centro, não porque ainda não chegamos a ele, mas porque não é possível tê-lo. A complexidade trabalha com a realidade das redes tendo como uma de suas características a ausência de centro. Há a ausência de previsibilidade, uma vez que não funciona o esquema causa-efeito e sim de sinergias que circulam e se afetam mutuamente. Assim, não há história, mas histórias.

O quarto é a passagem da secularização secularista ao niilismo. A secularização tem uma longa ligação com a modernidade. "Por secularização entendemos o processo pelo qual setores da sociedade e da cultura são subtraídos à dominação das instituições e símbolos religiosos" ${ }^{\prime 3}$. Se as ciências possibilitam descobrir o funcionamento do mundo através da descoberta da dupla causa-efeito, se o mundo caminha linearmente para o futuro de progresso e de civilização, então a religião pode ser retraída para o reino individual, à consciência das pessoas. $\mathrm{O}$ mundo é mundo, a religião é religião. Para muitos, no entanto, a religião não subsiste nem para o reino pessoal da consciência, mas foi eliminada por completo.

A nova época encontra este panorama. Do ponto de vista filosófico esta nova época significa a destruição de todo e qualquer fundamento, inclusive de Deus, não para colocar outro no lugar, mas para destrui-lo sem dó nem compaixão. Na realidade, este niilismo assume da modernidade que não é possível provar que Deus existe, mas avança dizendo que não é possível provar o seu contrário. Esta é a chance da religião e, segundo Vattimo, a responsável pelo grande renascimento religioso e espiritual neste início de século e de milênio. Na realidade não foi Deus quem morreu, foi a metafísica, o pensamento forte, as essências determinadas uma vez por todas.

O quinto é a passagem do código ético não-ambivalente à ética aporética. A modernidade trabalha com a ideia de que se há um pensamento forte, não-ambivalente, deve existir também um código ético forte. "Os filósofos definiram a universalidade como aquele traço das prescrições éticas que compelia toda criatura humana, só pelo fato de ser criatura humana, a reconhecê-lo como direito e aceitá-lo em consequencia como obrigatório" 39 . Se na Idade Média o código ético se fundamenta em Deus, na moderna ele se fundamenta na pessoa humana. Não há mais heteronomia (teonomia!), mas autonomia. Em moral não há ambivalências, nem incertezas. A certeza não pode viver com seu oposto. "Se as normas morais pregadas e/ou praticadas aqui e agora devem ter esta autoridade, é preciso mostrar que outras normas são não só diferentes, mas também erradas e más: que sua aceitação decorre de ignorância e imaturidade. Se não de má vontade"40.

Aqui, a nova época faz uma reflexão interessante. Se não há mais um pensamento forte, isto traz grande influência na reflexão ética. A ontologia é fraca. O pensamento

\footnotetext{
${ }^{37}$ ZEHR, H. Trocando as lentes, p. 103.

${ }^{38}$ BERGER, Peter. O dossel sagrado, p. 119.

${ }^{39}$ BAUMAN, Z. Ética pós-moderna, p. 13.

${ }^{40}$ BAUMAN, Z. Ética pós-moderna, p. 48.
} 
fraco propugna que não há pensamentos e que é impossível determinar de uma vez por todas a essência das coisas. Assim, o meu pensamento tem o mesmo valor que o pensamento do outro. O outro para mim é um apelo de reconhecimento, assim como eu para o outro sou outro apelo de reconhecimento. Na raiz de tudo não está uma ontologia, mas um apelo ético. O outro se apresenta para mim misterioso, complexo. Então, a ética também será misteriosa, complexa, ambivalente e aporética. Assim, não temos mais uma ética autônoma, mas heterônoma. O outro é para mim um grande apelo ético e, por assim dizer, o "fundamento" de toda a ética.

Por último, o sexto é a passagem da razão todo-poderosa à liberação da metáfora. Descartes em seu célebre axioma "penso, logo existo" chancelou a unilateralidade da pessoa humana a partir da racionalidade. Com seu outro axioma das "ideias claras e distintas" reduziu tremendamente a pessoa à todo-poderosa razão. Kant chega a afirmar que as emoções não são um fator moral. Ele admite que os sentimentos, assim como o agir por afeições, não têm nenhum significado moral - somente a escolha, a faculdade racional e as decisões que ela dita podem refletir sobre o agente como pessoa moral. A modernidade trabalha muito com a ideia de que a razão não é emocional e o emocional é não-racional. O único fundamento da vida é a razão. O resto é irracional, também as emoções.

A nova época afirma que além do racional existe o arracional. Ela não quer acabar com a racionalidade, apenas tirá-la do pedestal em que irracionalmente se colocou e colocá-la na horizontalidade das dimensões da vida e do mundo. Assim, há a liberação da metáfora. A vida humana é, sobretudo, mistério. Nem tudo cabe dentro de esquemas mentais e lógicos. Ela também é feita de silêncio, de admiração, de afeto, de graça.

\subsection{Educação para e na complexidade contra toda unidimensionalidade}

Reafirmamos que o maior problema do mundo é a unidimensionalidade. Muitas das dificuldades pelas quais passa o ensino religioso é, justamente, este olhar unidimensional. Há escolas em que só entrou a cabeça da pessoa e não seu coração, nem suas mãos e seus pés. São as famosas escolas conteudistas. Papa Francisco captou bem isto quando afirma

Desejo a todos um lindo caminho educacional, que faça crescer as três línguas que uma pessoa madura deve saber falar: a língua da mente, a língua do coração, a língua das mãos. Harmoniosamente, isto é, pensar o que se sente e o que se faz; sentir bem o que se pensa e o que se faz; e fazer bem o que se pensa e o que se sente ${ }^{41}$.

Há um movimento crescente no mundo chamado de homeschooling. Há pais que afirmam poder educar (schooling) seus filhos em casa (home-). O jornal Folha de São Paulo publicou a seguinte manchete: "Juiz condena pais por educar filhos em casa". Como subtítulo afirma: "sentença prevê multa e fala em 'abandono intelectual' dos jovens de 15 e 16 anos, tirados da escola há quatro anos, em Minas”42. A reportagem também afirma que este método chamado de homeschooling reúne cerca de um milhão de adeptos só nos EUA, embora organizações de aprendizado escolar domiciliar sugiram que o número real possa ser o dobro.

A existência deste movimento pode ser justificada por dois motivos antagônicos. O primeiro é que a sociedade não é capaz de captar o verdadeiro sentido da escola

\footnotetext{
${ }^{41}$ CNBB. Pastoral da Educação, p. 11.

${ }^{42}$ BASSETTE, F. Juiz condena pais por educar filhos em casa, em 06/03/2010.
} 
e, pelo que ela faz, os pais dizem que tanto faz educar em casa quanto na escola que dá na mesma. Se a escola tem a única missão de passar conteúdos intelectuais, a homeschooling é capaz de fazê-lo e até com mais eficiência. A teoria da complexidade coloca em xeque esta escola unidimensional. Se a escola é assim, é porque a visão que se tem de ciência é assim. Ela não é capaz, hegemonicamente, de ter uma visão mais holística da realidade. No mundo vigora a mais pura unidimensionalidade e a complexidade passa ao largo.

As especializações não acabarão. São importantes. No entanto, precisam estar conectadas com o todo. Também as escolas não podem mais trabalhar de forma tão seccionada, tão disciplinar. Quando surgirão as escolas sem seriação, sem disciplinas como gavetas? Certamente que a net com bilhões de informações solapa aos poucos um dos grandes pilares da escola que é a transmissão do saber acumulado através dos tempos, embora as crianças pobres precisem da escola também para esta função. À escola compete trabalhar em rede repercutindo o que as novas gerações fazem conectando e como se conectam, realizando sínteses e propondo novos desafios, hipóteses e caminhos.

Em relação à homeschooling, no Brasil, até hoje, nenhum juiz deu ganho de causa para qualquer pai que quis educar seus filhos em casa, sem passar pela escola. Isto é compreensível porque a escola não é a continuação da família. Pelo contrário, ela é a ruptura com a família. Numa sociedade pluralista, as novas gerações precisam ser educadas junto com outras crianças e adolescentes. Nenhuma família e nenhuma pessoa é um condomínio fechado. A escola é um desenho do que é a sociedade. Toda criança precisa encontrar-se com crianças com outras vivências e concepções de vida de todos os tipos: políticas, culturais, religiosas, econômicas, sociais, éticas. Como uma criança vai ter noção de etnia se não convive com as diferentes etnias? Como pode ter uma noção de gênero se não convive com o gênero diferente? O professor não é um computador ambulante, ele não é uma enciclopédia ambulante. Certamente que todo professor passa, transmite os assim chamados conteúdos. Uma boa escola tem que fazer isto. No entanto, todo professor é mais que isto. Ele é um mediador cultural. Toda sala de aula é um espaço de convivência com o diferente e os diferentes. A escola é um ambiente de atitude e de socialização e não apenas um lugar onde se ensina conhecimentos gerais. Mesmo que os pais pudessem passar os conteúdos em casa para seus filhos, eles não conseguem passar uma visão plural da sociedade, mais que isto, uma vivência plural da sociedade. Escola é mais que um prédio, é mais que uma sala de aula, um computador e uma biblioteca. Escola é encontro de diferenças e de diferentes.

Por isso também é que se deve repelir a escola única. Há um pluralismo de escolas. $\mathrm{O}$ financiamento da educação deveria ser único. Há países que fazem assim. No Chile, por exemplo, há diversidade de escolas: tanto as mantidas pelo estado quanto as mantidas por grupos organizados. Agora, o financiamento da educação é sempre competência do estado. Todas as escolas são gratuitas, tanto as do estado quanto as dos grupos organizados. Aí, sim, há possibilidade de opção de ensino. No Brasil, infelizmente, esta realidade nos parece impossível de acontecer. Há os estatizantes que afirmam que “dinheiro público é para escolas públicas”, identificando público com estatal. Há, além disso, os privatizantes que dizem que as escolas mantidas por grupos organizados não devem receber dinheiro do estado porque precisam inserir-se no mercado e submeterse às suas regras. A consequência desta visão é óbvia. A escola mantida pelo poder público estatal continua não recebendo os recursos necessários destinando-se quase que exclusivamente às camadas populares, sobretudo na educação básica. Por outro lado, lançadas no mercado, as escolas mantidas por grupos organizados só podem ser frequentadas pelas classes mais abastadas ou pela sofrida classe média. Até quando 
esta visão deve prevalecer? Os impostos são pagos por todos os cidadãos. Portanto, onde está o cidadão aí está o estado e também os recursos do estado. Não é possível boa escola particular se não houver boa escola pública.

A ciência moderna com sua linearidade de causa-efeito restringiu por demais as possibilidades humanas. Não resta dúvida que contribuiu sobremaneira para o progresso técnico e tecnológico. No entanto, não conseguiu criar perspectivas éticas para a humanidade, que não fossem a de dominação e de exploração em grande escala. O pensamento complexo, ao contrário, vem quebrar esta unidimensionalidade. $\mathrm{O}$ universo não é mais visto como uma máquina ou um relógio, mas como um todo dinâmico, indivisível, cujas partes estão essencialmente inter-relacionadas e só podem ser entendidas como modelos de um processo cósmico. O mundo está ameaçado porque a vida está ameaçada. A pessoa humana, ao mesmo tempo em que é parte de todo este processo, é também estranha a ele. Ela sofre suas consequências, mas ao mesmo tempo interfere em suas causas. Dentro do princípio da retroalimentação, ela é causa e efeito, ao mesmo tempo. Sofre e faz sofrer, mas também ama e é amada.

O homem contemporâneo experimentou que o que acontece em uma parte do mundo pode ter consequências em outras, e que ninguém pode, a priori, sentir-se seguro em um mundo em que há sofrimento e miséria ${ }^{43}$.

A vida humana é, sobretudo mistério. Nem tudo cabe dentro de esquemas lógicos e mentais. Ela também é feita de silêncio, de admiração, de afeto, de emoção, de graça. Uma criança de rua, um mendigo, um drogado, um aidético não são apenas vítimas sacrificiais da mística cruel do mercado. A fé cristã diz que são filhos queridos de Deus Pai e Mãe: “Antes de modelar-te no seio de tua mãe, antes de saíres do ventre, eu te conhecia, eu te consagrei" ( $J r 1,5)$.

Tanto a reflexão filosófica e teológica quanto a pedagógica latino-americanas foram elaboradas, quase que exclusivamente, com instrumentos da modernidade ilustrada. Na modernidade ilustrada o "mesmo" da autoafirmação identitária, totalizante, mata $o$ outro. Chegou a hora de elaborá-la a partir da própria razão simbólica, de forte raiz latino-americana. Frente ao mundo da razão lógica instrumental e matemática, a razão simbólica, metafórica, enfatiza o mundo do coração, da vivência, da experiência, da religião, com seus símbolos e ritos. Não se preocupa somente com os meios ou instrumentos, e sim com os fins, com o para quê e para onde.

Diante do mundo ocidental tão machista, inclui a mulher, mais intuitiva e profunda. Diante da consideração absolutizante da história e do progresso, realça a importância da natureza, do cosmo, da terra, como sacramento do religioso. Diante do mundo da violência, busca a utopia da não-violência, pois a razão simbólica é vital e está apegada às fontes da vida. Diante da eficácia da práxis, privilegia a festa, e diante do serviço, propicia a comunhão; não somente ser para os demais (Bonhoeffer), mas sim, estar com os demais, partilhar, compartilhar. Diante da universalidade do racional e do técnico, valoriza o pluralismo, o nacional, a pátria, a família, a casa, as línguas, as culturas, a memória, o relato. Diante da acentuação unilateral da ética, sublinha a estética, o formoso, o belo. Não somente usar, mas também des-frutar ${ }^{44}$.

\footnotetext{
${ }^{43}$ CONGREGAÇÃO PARA A EDUCAÇÃO CATÓLICA. Educar ao humanismo solidário, p. 9.

${ }^{44}$ CODINA, V. Creio no Espírito Santo, p. 176.
} 


\subsection{Educação em defesa da vida}

Há alguns direitos naturais que são fundamentais para a cada pessoa humana. São clássicos quatro direitos. O direito à vida, decorrente da inclinação natural à auto conservação; o direito à constituição da família, decorrente da inclinação natural à conservação da espécie; o direito à verdade decorrente da inclinação natural ao conhecimento; o direito à liberdade e à igualdade decorrente da inclinação natural à vida em sociedade.

Os processos educativos são muito mais eficazes na defesa e promoção da vida que os processos ditatoriais. Estes visam impor posições hegemônicas de grupos dominantes em detrimento de posições de minorias da sociedade.

José M. Castillo, em seu livro "Jesus, a humanização de Deus", afirma que há três elementos constitutivos básicos e elementares em todos os seres humanos. Por isso afirma que é necessário defender o minimamente humano para todos. Ele faz uma leitura da vida de Jesus neste sentido. Embora longa, é importante fazermos esta citação

Tais elementos são: 1) Todos os seres humanos somos, antes de tudo, seres vivos de carne e osso. Desse ponto de vista, pode-se assegurar que onde falta a condição carnal ou, se preferimos, a carnalidade, não há e nem pode haver um ser humano. 2) Todos os seres humanos somos seres sociais. Portanto, a relação com outros seres humanos, a relação de alteridade, também é constitutiva de todo ser humano. 3) Todos os seres humanos somos seres individuais. Isso quer dizer que todos temos nossa condição pessoal que inclui a capacidade de decidir, ou seja, a liberdade. Sem esses três elementos constitutivos, parece que não podemos falar de "ser humano" algum ${ }^{45}$.

Esses três elementos estão profundamente imbricados, interdependentes que, sem um deles não é possível a existência do outro. Afirmamos que a nova época histórica afirma que no princípio não está a ontologia, mas a ética. O nascimento de uma pessoa depende da liberdade e da aceitação de outra. Sem o outro não há nascimento. O mesmo se diga da existência de quem nasce. Sem a benevolência terna, materna e paterna, não há geração do outro. A vida humana é um fato ético. Existir é fruto da liberdade do outro e de sua benignidade. Continuar existindo também é fruto da liberdade do outro e de sua benevolência. Morrer de fome e de inanição é fruto de um mundo sem padrões éticos e sem respeito à alteridade. A sacralidade da vida é o fato ético fundante, independentemente de qualquer conotação religiosa e ideológica.

Estamos vivendo um extraordinário progresso tecnológico. Estamos ingressando fortemente na chamada geração 4.0. A humanidade inteira sempre desejou melhorar as condições de vida e de trabalho. Os escravos da antiguidade, os trabalhadores da gleba medievais, os operários dos campos e das indústrias construíram a possibilidade do progresso extraordinário de hoje. Sem eles o que vivemos ou poderíamos viver hoje não se torna possível. Não é justo que apenas um grupo de pessoas se apodere de todo o suor de gerações e gerações e desfrute dos benefícios condenando bilhões de pessoas à marginalização e à exclusão. Hoje se torna cada vez mais possível colocar os bens da criação a serviço de todos os homens e mulheres da terra. Ninguém nasceu para sofrer à toa e nem para morrer na tenra idade. Sem ciência e tecnologia não há possibilidade de construir vida digna para todos, mas também só ciência e tecnologia não é capaz de

${ }^{45}$ CASTILlO, J. M. Jesus: a humanização de Deus, p. 283. 
respeitar aos anseios de vida em abundância para todos. Nesta missão participa também com sua pequena, mas significativa contribuição o ensino religioso.

A Igreja assume quatro princípios permanentes de sua Doutrina Social: o princípio personalista que promove sempre e em todos os tempos a dignidade de cada uma e de todas as pessoas humanas; o princípio do bem comum que protege a destinação de todos os bens para todas as pessoas inclusive as que não nasceram ainda e as gerações futuras; o princípio da subsidiariedade que promove a participação de todos nos destinos da humanidade; o princípio da solidariedade, sobretudo com os que mais sofrem.

Deus deu a terra a todo gênero humano para que ela sustente todos os seus membros sem excluir nem privilegiar ninguém. Está aqui a raiz da destinação universal dos bens da terra. Deus destinou a terra e tudo o que ela contém para o uso de todos os homens e de todos os povos, de sorte que os bens criados devem chegar equitativamente às mãos de todos, segundo a regra da justiça, inseparável da caridade ${ }^{46}$.

\subsection{Educação mais do direito que da lei, mais da ética que da moral}

Os autores atualmente costumam fazer uma distinção entre lei e direito. Só existe lei quando há a chancela de uma autoridade que a promulga. A lei vale unicamente para uma nação e para um grupo determinado. Elas não são imutáveis. O direito, ao contrário, não depende de nenhuma autoridade humana. Os antigos gregos através da boca de Antígona diziam que o direito "faz parte das leis não escritas e indestrutíveis pelos deuses". Ele é universal e não se limita nem pelo tempo e nem pelo espaço. Por isso, o direito é superior à lei. Não é a lei que orienta o direito, mas é o direito que orienta a lei. Tem muita gente que tem respeito pela lei, mas não tem respeito pelo direito. Aplica a lei ao pé da letra sem dar-se conta de que ela tem que ser lida à luz do direito. O importante sempre é colocar o direito como horizonte de vida e a lei como aplicação deste direito.

É muito importante fazer uma distinção entre ética e moral. Moral é o instituído. Ética é o instituinte. Moral são as leis, as normas, os regulamentos, as constituições, os códigos. Ética é o grande projeto de vida, o horizonte, a utopia. Reduzir a vida humana e cristã à moral é empobrecer a vida. A moral pode mudar de acordo com o tempo. A ética ajuda a moral a mudar para ser mais humana. Embora as normas morais representem a experiência acumulada de uma sociedade, muitas vezes estas normas estão longe da ética. É só olharmos o caso da escravidão, da posição da mulher na vida privada e na vida social, o direito dos portadores de necessidades especiais, a grande discriminação sofrida pelos suicidas, pelos leprosos, pelos doentes mentais...

Em educação é fundamental estas distinções. Nada do que falamos até aqui tem qualquer significação e sentido para homens e mulheres que assumiram posturas light em sua vida. Estas pessoas vivem, pragmaticamente, a tetralogia do hedonismopermissivismo-consumismo-relativismo que se mantém unidos por um forte senso de materialismo. Na Bíblia existem três fatos que mostram claramente a distinção entre lei e direito, moral e ética.

${ }^{46}$ JOÃO PAULO II. Carta Encíclica Centesimus Annus, n. 31. 


\subsubsection{As parteiras do Exxodo 1, 15-22}

Vamos sintetizar a narração do fato. O faraó convocou todas as parteiras hebreias e mandou que elas matassem, no momento do nascimento, todos os meninos. Esta é a lei. O que fizeram as parteiras? Desobedeceram ao Faraó: "As parteiras temeram a Deus e não fizeram o que o rei do Egito lhes havia ordenado e deixaram os meninos viver" (Ex 1,17). Este é o direito. É um exemplo típico de desobediência civil. O que levou as parteiras a desobedecerem ao faraó? O temor de Deus.

O faraó convoca as parteiras e lhes pede explicação. Elas respondem que não puderam agir porque as mulheres dos hebreus são mais vigorosas que as do Egito e, elas, as parteiras, chegam sempre tarde demais. O faraó fica mudo. Por quê? Porque não pode contestá-las uma vez que no Egito antigo nenhum homem podia assistir ao parto de nenhuma criança. A autoridade do faraó não é divina porque não pode comprovar o que dizem as parteiras.

$\mathrm{O}$ direito à vida é superior a qualquer lei, mesmo vinda do faraó. Este é um direito fundamental não escrito, um princípio, um código moral fundamental e universal.

\subsubsection{O nascimento de Moisés em Êxodo 2,1-10}

A personagem principal desta cena é a filha do faraó e não Moisés. Sua vida está nas mãos da filha do faraó. Ela seria a primeira que deveria aplicar a lei imposta pelo faraó, isto é, matar os meninos dos hebreus logo que nascessem. O relato mostra que, diante do recém-nascido que chora no cesto de juncos, a voz profunda da natureza humana fala mais alto do que a do dever, e a filha do faraó salva o menino. Isto vem dizer que a ordem do faraó é contra a natureza porque até sua filha desobedece. Este agir é um grito contra as leis injustas que se cristalizam na sociedade.

\subsubsection{Resfa, esposa de Saul (2 Sm 21,1-14)}

No tempo do rei Davi houve uma grande carestia. Segundo a mentalidade da época, alguém é culpado por isso. Davi pesquisa e descobre que havia um delito cometido pelo rei Saul contra os gabaonitas. O primeiro rei de Israel tinha procurado exterminar aquela população não israelita, enquanto Israel, no tempo de Josué, tinha prometido salvar a vida dela.

Descoberto o motivo: é preciso reparar o crime. O que fazer? Os gabaonitas querem que sete membros da família de Saul sejam submetidos ao suplício diante do Senhor em Gabaon de Saul. O derramamento de sangue da família de Saul é a compensação. A vida deles pagará pelas vidas dos gabaonitas assassinados. No meio dos sete que serão esquartejados há dois filhos de Resfa, concubina de Saul. Ela fica ao lado dos corpos e "não deixou descerem as aves do céu sobre eles durante o dia, nem os animais selvagens se aproximarem durante a noite" (Ex 21,10). Permaneceu mais de seis meses no mesmo lugar para proteger o corpo de seus filhos. Com a chegada das chuvas a terra produzirá uma nova colheita e acabará a carestia.

Davi, sabendo disso, manda enterrar os filhos de Resfa, os outros cinco filhos de Micol e aproveita também para recuperar os restos mortais de Saul e de Jônatas, seu filho que foi também seu amigo. Todos são enterrados.

Resfa defende o direito de sepultura dos seus filhos. Davi encarna a lei, pois entrega os setes descendentes de Saul para serem esquartejados. Contra isso Resfa não pode fazer nada. Resfa, representa o direito, pois defende o direito de sepultura para seus 
filhos. Novamente é a lei injusta contra o direito: os corpos deveriam ficar expostos até o final da carestia. Se é assim, ela os protege e os leva até a sepultura. Toda pessoa tem direito à sepultura honrosa.

A lição maior destes relatos é que há sempre pessoas sensíveis e misericordiosas capazes de recolher em seu coração, sua cabeça e suas mãos as lágrimas de tantos injustiçados por leis injustas que não acabam nunca.

Um educador que tem o coração sabe que nem sempre a aplicação rigorosa da lei é suficiente. Acima disso está o direito inscrito no coração, na tradição e na vida dos povos, sobretudo dos mais fracos. Quanto sofrimento os educadores têm que assistir porque os jovens são olhados mais como uma questão policial e não como um desafio social. Mais que um problema, eles são o que a sociedade decidir que são: ou delinquentes ou o presente e o futuro da nação.

\subsection{Educação aberta ao transcendente encarnado}

A encarnação de Jesus Cristo é a afirmação de que Deus se fez história, se fez humano, faz caminhada concreta com o povo. Para o cristão, Deus é transcendente e imanente ao mesmo tempo. Ele se fez humano para nos tornar divinos. Nós temos acesso a Ele não diretamente em sua transcendência, mas em sua imanência. A encarnação de Deus em Jesus é a certeza de que não há caminhos paralelos nem entre Ele e os humanos e nem estes entre si. Ao mesmo tempo é a revelação de que não há duas histórias, uma sagrada e uma profana, mas apenas uma.

O anúncio cristão é mais exatamente um evento histórico, não a revelação, por parte de Cristo, de uma verdade eterna. Jesus Cristo, para o cristão, pessoa viva, evento significativo, é paradigma para todo o que nele crê. Vida, paixão, morte e ressurreição de Jesus é paradigmático para todos que o aceitam como ideal de vida. Os primeiros cristãos eram chamados os do caminho. Quem quer seguir a Jesus Cristo deve fazer seu caminho. Sua vida, paixão, morte e ressurreição é como se fosse o mirante, o belvedere da história. Todo a Antiga Aliança pode ser interpretada a partir dele. É uma história que deu certo porque desabrochou em Jesus Cristo Ressuscitado, melhor presente que Deus poderia ter feito ao mundo e melhor presente que o mundo poderia oferecer a Deus. Jesus interpretou a história e a fez avançar. "Ouvistes o que foi dito" e "eu, porém vos digo" está colocada numa perspectiva de fidelidade dinâmica. Ser fiel não é ser perseverante no mesmo. Ser fiel é abrir-se para o outro, para o novo, para a complexidade, para a rede, desencadear processos, fazer caminhada. A partir da encarnação de Jesus Cristo, o apelo para avançarem na direção do novo, da natalidade, é feito não apenas aos seus seguidores, mas a todos.

O pensamento fraco é o caminho para o diálogo religioso cristão porque é o caminho evangélico escolhido por Deus que faz com que seja possível o pluralismo e até a sua negação. A grande revelação de Deus aconteceu na fraqueza, na kénosis:

Haja entre vós o mesmo sentir e penar que no Cristo Jesus. Ele, existindo em forma divina, não considerou como presa a agarrar o ser igual a Deus, mas despojou-se, assumindo a forma de escravo e tornando-se igual ao ser humano. Aparecendo como qualquer homem, humilhou-se, fazendo-se obediente até a morte - e morte de cruz! Por isso, Deus o exaltou acima de tudo e lhe deu o Nome que está acima de todo nome, para que, em o Nome de Jesus, todo joelho se dobre no céu, na terra e abaixo da terra, e toda língua confesse: "Jesus Cristo é o Senhor", para a glória de Deus Pai $(F l 2,5-11)$. 
A cruz de Jesus Cristo significa rebaixamento, humilhação, enfraquecimento de Deus para quebrar todos os fundamentalismos e totalitarismos do mundo. Como não há duas histórias, mas uma só, quebrar todos os fundamentalismos e totalitarismos de toda espécie: religiosos, culturais, políticos e econômicos. "Pensar em um curso da história que seja orientado na direção da emancipação através da consumação de estruturas fortes - do pensamento, da consciência individual, do poder político, dos laços sociais, da própria religião" 47 , não condiz com a mensagem evangélica da kénosis.

Falando sobre os novos pelagianos que atribuem tudo a si mesmos e não à graça de Deus, o Papa Francisco mostra como ele se apresenta hoje, bem contrário á kénosis da carta aos Filipenses.

Manifesta-se em muitas atitudes aparentemente diferentes entre si: a obsessão pela lei, o fascínio de exigir conquistas sociais e políticas, a ostentação no cuidado da liturgia, da doutrina e do prestígio da Igreja, a vanglória ligada à gestão de assuntos práticos, a atração pelas dinâmicas de autoajuda e realização autorreferencial. É nisto que alguns cristãos gastam as suas energias e o seu tempo, em vez de se deixarem guiar pelo Espírito no caminho do amor, apaixonarem-se por comunicar a beleza e a alaegria do Evangelho e procurarem os afastados nessas imensas multidões sedentas de Cristo ${ }^{48}$.

A ressurreição de Jesus vem afirmar que Deus não se coloca do lado dos que crucificam, dos que excluem, mas sim do lado dos crucificados. O cristianismo não é um messianismo. À medida que o anúncio do Reino se divulgava na Galiléia, crescia no povo a expectativa messiânica e aumentava sobre Jesus a pressão para aceitar o papel do Messias que os outros esperavam. Esta tentação acompanhou Jesus do começo ao fim. A pressão vinha de todos os lados. Pessoas, fatos, situações, todos tentavam desviá-lo do caminho assumido como servo de Javé e Filho do Homem. No deserto foi-lhe proposto

o caminho do messias-novo-Moisés que alimenta o povo no deserto (Mt 4,3), do messias desconhecido que, de repente, se manifesta publicamente (Mt 4,5-6; Jo 7,27), e do messias nacionalista que conquista o domínio sobre o mundo inteiro $(M t 4,9)$. Jesus reage com força, condenado a proposta com palavras da Escritura $(M t \text { 4,4.7.10 })^{49}$.

Paul Tillich diz que a linguagem da espiritualidade é a linguagem do paradoxo. O paradoxo aceita a verdade de duas idéias incompatíveis na ordem da lógica como asserções necessárias e inteligíveis na ordem da existência. O paradoxo libera as nossas categorias lógicas de se perderem em si mesmas e nos possibilita a visão do infinito trans-racional. Quando o finito fala do infinito, sabe que sua fala é verdadeira e falsa ao mesmo tempo. "Tillich acreditava que o paradoxo situava-se no centro da compreensão da mensagem cristã do Novo Ser, da nova criatura em Cristo, representada especialmente na figura do Crucificado" ${ }^{50}$. Seus sermões estão repletos de paradoxos, a partir da Kénosis de Deus em Jesus Cristo.

Quem busca a salvação divina de forma visível não pode ver a criança divina na manjedoura nem a divindade do Homem na Cruz nem o modo paradoxal da ação divina. A salvação é uma criança que será crucificada quando crescer.

\footnotetext{
${ }^{47}$ VATTIMO, G. Depois da cristandade, p. 115.

${ }^{48}$ FRANCISCO, Exortação apostólica do papa Francisco Gaudete et Exsultate sobre o chamado à santidade no mundo atual, n. 57.

${ }^{49}$ MESTERS, C. Com Jesus na contramão, p. 111.

${ }^{50}$ PARRELLA, F. Vida e espiritualidade no pensamento de Paul Tillich, p. 13.
} 
Só os que conseguem ver poder na fraqueza, a totalidade nos fragmentos, a vitória no fracasso, a glória no sofrimento, a inocência na culpa, a santidade no pecado e a vida na morte poderão dizer: meus olhos viram a tua salvação ${ }^{51}$.

Em seus sermões Tillich usa muito a linguagem do paradoxo. Há uma série deles em rápidas frases que são muito elucidativas. Citaremos algumas delas. "Deus age além da expectativa humana [porque] dá poder aos fracos e fortalece os destituídos paradoxalmente. Deus age além da compreensão humana". "Nós só temos Deus quando não o temos". "Acreditem que vocês são aceitos apesar de não serem aceitáveis". "Nenhum poder maior ou mais alta sabedoria poderia revelar mais plenamente o coração de Deus e o coração do homem do que o Crucificado". "A imagem do Altíssimo é Jesus na cruz. Sua alma sofredora não foi quebrada pelos poderes do universo". "O homem na cruz representa outra ordem na qual os mais fracos se fazem fortes e os mais humilhados os vencedores" ${ }^{52}$.

\section{CONCLUSÃO}

Em toda a reflexão que fizemos é importante levarmos em consideração que no seu fundamento está a convicção de que o cristão não pode ser genérico mas bem específico. O que significa isto? A vida do cristão não é indiferente para a vivência de sua fé. Cada cristão é uma missão. Não existe um clichê de cristão. $O$ específico de cada um é a missão que desempenha na família, na sociedade e na Igreja. No caso da pastoral da educação, por exemplo, o específico do professor é sua missão em sua ciência específica. Assim, um professor de língua portuguesa é cristão enquanto ensina as novas gerações a se comunicar da melhor maneira possível. Além disso, o professor de língua protuguesa pode ajudar na compreensão dos textos fundantes e fundamentais de todas as religiões. Quem não entende de figuras de linguagem, como pode entender a Bíblia? O professor de física ensina os elementos para entender a natureza e seus fenômenos, ajudando a eliminar a consciência ingênua. Além disso, os grandes insights de espiritualidade são dados também por físicos como Fritof Capra. O coordenador pedagógico pode organizar a escola na linha da transdisciplinaridade, neste caso ele evangeliza a escola. A tarefa de todos é contribuir com os outros educadores de outras crenças e os ateus a educar as novas gerações para que o mundo seja entendido em sua complexidade para uma convivência humana mais adequada e uma resposta mais consistente ao sentido da vida.

Para ser santo não é necessário ser bispo, sacerdote, religiosa ou religioso. Muitas vezes somos tentados a pensar que a santidade esteja reservada apenas àqueles que têm possibilidade de se afastar das ocupações comuns, para dedicar muito tempo à oração. Não é assim. Todos somos chamados a ser santos, vivendo com amor e oferecendo o próprio testemunho nas ocupações de cada dia, onde cada um se encontra. És uma consagrada ou um consagrado? Sê santo, vivendo com alegria a tua doação. Estás casado? Sê santo, amando e cuidando do teu marido ou da tua esposa, como Cristo fez com a Igreja. És trabalhador? Sê santo, cumprindo com honestidade e competência o teu trabalho ao serviço dos irmãos. És progenitor, avô ou avó? Sê santo, ensinando com paciência as crianças a seguirem Jesus. Estás investido em autoridade? Sê santo, lutando pelo bem comum e renunciando aos teus interesses pessoais ${ }^{53}$.

${ }^{51}$ TILLICH apud PARRELLA, F. Vida e espiritualidade, p. 13.

${ }^{52}$ Cf. TILLICH apud PARRELLA, F. Vida e espiritualidade, p. 14.

${ }^{53}$ FRANCISCO, Gaudete et Exsultate, n. 14. 
Como vimos, estas reflexões são feitas a partir da perspectiva católica. A catolicidade se manifesta na universalidade com que se olha toda a realidade: através do todo, para todos. Em suma, não mais hostilidade, mas na hospitalidade. A catolicidade, hoje, significa abertura e diálogo com a pessoa toda e com todas as pessoas. Esta talvez seja a palavra que mais expressa que o ensino religioso tem que ser católico $e$ de outras religiões. Nós somos complexos em nosso nome. Exerçamos a hospitalidade para com todos numa dimensão holística (holos). Somos imagem e semelhança de Deus porque Ele é Uno e Trino. Nós somos muitos, mas tão solidários que somos Um. À luz da Trindade somos capazes de ser plurais e, ao mesmo tempo, um. A Trindade Una - Pai, Filho e Espírito Santo - é capaz de acolher em si a pluralidade das três pessoas divinas. Este é o grande Mistério. Diante dele, silenciamos e contemplamos...

Rejeitando o laicismo e acolhendo a laicidade do Estado, a Igreja entende que "é próprio do estado dos leigos viver no meio do mundo e das ocupações seculares, por isso, eles são chamados por Deus para, cheios do fervor cristão, exercerem, como fermento, seu apostolado no meio do mundo" ( $A A$ 2). Se o ensino religioso está presente na escola brasileira muito se deve ao empenho de pais, professores, alunos, gestores, na sua presença em nosso ordenamento jurídico e, sobretudo, na prática efetiva nas escolas de todos os sistemas de ensino. "A educação será tanto mais humanizadora quanto mais se abrir para a transcendência, ou seja, para a verdade e o Sumo Bem" ${ }^{4}$.

\section{REFERÊNCIAS}

III CONFERENCIA GENERAL DEL EPISCOPADO LATINO-AMERICANO, Puebla. Conclusões. Evangelização no presente e no futuro da América Latina, São Paulo 1979.

ALBERTON, G. da S. Laicidade na Relação Igreja-Estado e o Acordo Brasil-Santa Sé. Curitiba: Prismas, 2015.

ANJOS, M. F. dos; ITOZ, S. de; JUNQUEIRA, S. R. A. Pastoral Escolar. Práticas e Provocações. Aparecida: Santuário, 2015.

BASSETTE, F. Juiz condena pais por educar filhos em casa. Jornal Folha de São Paulo, São Paulo, Caderno C1. Em 06/03/2010.

BAUMAN, Z. Ética pós-moderna. 2. ed. São Paulo: Paulus, 2003.

BERGER, Peter. $O$ dossel sagrado. Elementos para uma teoria sociológica da religião. 4.ed. São Paulo: Paulus, 2003. (Sociologia e Religião, 2).

BOFF, Leonardo. Ética e Moral. A busca dos fundamentos. 2. ed. Petrópolis: Vozes, 2004.

Virtudes para um outro mundo possível. Vol. 1: Hospitalidade: Direito \& Dever de todos. Petrópolis: Vozes, 2005.

BRASIL. Constituição Federal de 1988. 4. ed., São Paulo: Oliveira Mendes, 1999.

CAPRA, F. O ponto de mutação. A ciência, a sociedade e a cultura emergente. São Paulo: Cultrix, 1982.

CAStillo, J. M. Jesus: a humanização de Deus: ensaio de cristologia. Petrópolis: Vozes, 2015.

CNBB. Para uma pastoral da educação. São Paulo: Paulinas, 1986. (Estudos da CNBB, 41).

. Educação, Igreja e Sociedade. São Paulo: Paulinas, 1992. (Documentos da CNBB, 47).

${ }^{54} \mathrm{CNBB}$, Pensando o Brasil: educação, p. 47. 
CNBB. Pastoral da Educação: estudo para diretrizes nacionais. Brasília: Edições CNBB, 2016. (Estudos da CNBB, 110). . Pensando o Brasil: educação. Brasília: Edições CNBB, 2017. (Pensando o Brasil, 4). Fé cristã e laicidade. Brasília: Edições CNBB, 2018. (Subsídios Doutrinais, 10).

CODINA, V. Creio no Espírito Santo. Pneumatologia narrativa. São Paulo: Paulinas, 1997. COLOM, A. J. A (des) construção do conhecimento pedagógico: novas perspectivas para a Educação. Porto Alegre: Artmed, 2004.

CONGREGAÇÃO PRA A EDUCAÇÃO CATÓLICA. Educar ao humanismo solidário. Para construir uma “civilização do amor" 50 anos após a Populorum Progressio. Orientações. Brasília: Edições CNBB, 2018. (Documentos da Igreja, 41).

FRANCISCO. Audiência Geral (9.10.2013), Cidade do Vaticano. Disponível em: <http://w2.vatican. $\mathrm{va} /$ content/francesco/pt/audiences/2013/documents/papa-francesco_20131009_udienza-generale. html>. Acesso em: 20.08.2018.

Constituição Apostólica Veritatis Gaudium sobre as Universidades e as Faculdades Eclesiásticas. São Paulo: Paulinas, 2018.

. Exortação apostólica do papa Francisco Gaudete et Exsultate sobre o chamado à santidade no mundo atual. São Paulo: Paulus, 2018.

GRUEN, W. O Ensino Religioso na escola oficial. In: Atualização, Belo Horizonte, n. 64/65, p. 127-143, abr.-maio 1975.

. O Ensino Religioso em movimento. In: BOEING, A.; ITOZ, S. (Org.). O Ensino Religioso no projeto pedagógico pastoral salesiano. Brasilia: Rede Salesiana de Escolas, 2013. v. 2.

JOÃO PAULO II. Carta Encíclica Centesimus Annus. 5.ed. São Paulo: Paulinas, 2002.

. Universidades Católicas. Constituição Apostólica do Sumo Pontífice João Paulo II. 4. ed. São Paulo: Paulinas, 2004.

LIBÂNIO, J. B. A religião no início do milênio. São Paulo: Loyola, 2002.

. Crer num mundo de muitas crenças e pouca libertação. São Paulo: Paulinas, 2003.

. Introdução à Teologoia. Perfil, enfoques, tarefas. São Paulo: Loyola, 1996.

MELlo, C. de. Voto. Arguição de Descumprimento de Preceito Fundamental 54 (12.4.2012). Distrito Federal. Disponível em: <http://redir.stf.jus.br/paginadorpub/paginador.jsp?docTP=TP\& docID $=3707334>$. Acesso em: 25 ago. 2018 .

. Voto. Ação Direta de inconstitucionalidade, n. 4.451 (21.06.2018). Distrito Federal. Disponível em: <http://www.stf.jus.br/arquivo/cms/noticiaNoticiaStf/anexo/ADI4451VotoMCM.pdf>. Acesso em: 25 ago. 2018.

MESTERS, C. Com Jesus na contramão. São Paulo: Paulinas, 1995.

PARRELlA, F. Vida e espiritualidade no pensamento de Paul Tillich. Correlatio, São Paulo, n. 6, p. 48-70. nov. 2004.

RUEDELL, P. Trajetória do Ensino Religioso no Brasil e no Rio Grande do Sul. Legislação e Prática. Porto Alegre: Sulina; Canoas: UNILASALLE, 2005.

SENADO FEDERAL. Lei de Diretrizes e Bases da Educação Nacional. Brasília, 2005. Disponível em: <https://www2.senado.leg.br/bdsf/bitstream/handle/id/70320/65.pdf>. Acesso em: 20 ago. 2018.

SUSIN, L. C. O ato de religião como virtude e seus vícios. Sobre fundamentalismo, fanatismo, esquizocrentes: patologias e remédios. In: MILLEN, M. I. de C. (Org.). Fundamentalismo: desafios à ética teológica. Aparecida: Santuário, 2017. p. 195-222,

TILLICH, P. Teologia sistemática. 5. ed. revista. São Leopoldo: Sinodal, 2005.

TÔRRES, J. C. de O. A democracia coroada. 2. ed. Petrópolis: Vozes, 1964. 
VATTIMO, G. Depois da cristandade. Por um Cristianismo não religioso. Rio de Janeiro: Record, 2004.

YUS, R. Educação integral. Uma educação holística para o século XXI. Porto Alegre: Artmed, 2002.

ZEHR, H. Trocando as lentes. Justiça restaurativa para o nosso tempo. São Paulo: Palas Athena, 2008.

Recebido em: 15/08/2018

Aprovado em: 27/11/2018 